\title{
Kant's Political Religion: The Transparency of Perpetual Peace and the Highest Good
}

\author{
Robert S. Taylor
}

\begin{abstract}
Scholars have long debated the relationship between Kant's doctrine of right and his doctrine of virtue (including his moral religion or ethico-theology), which are the two branches of his moral philosophy. This article will examine the intimate connection in his practical philosophy between perpetual peace and the highest good, between political and ethico-religious communities, and between the types of transparency peculiar to each. It will show how domestic and international right provides a framework for the development of ethical communities, including a kingdom of ends and even the noumenal ethical community of an afterlife, and how the transparency and trust achieved in these communities are anticipated in rightful political society by publicity and the mutual confidence among citizens that it engenders. Finally, it will explore the implications of this synthesis of Kant's political and religious philosophies for contemporary Kantian political theories, especially those of Jürgen Habermas and John Rawls.
\end{abstract}

\section{Introduction}

Scholars have long debated the relationship between Kant's doctrine of virtue (including his moral religion or ethico-theology) and his doctrine of right, which are the two branches of his moral philosophy. Some commentators, such as Allen Wood, have argued for their independence from one another, suggesting that political mechanisms exist merely to advance our natural end of happiness and that publicity in the definition, justification, and implementation of principles of justice is just a lubricant to enhance the operation of these mechanisms. ${ }^{1}$ Others, however, have argued for a more intimate connection between the two doctrines. Patrick Riley, for example,

I wish to thank Lucy Allais, Henry Allison, Lanier Anderson, Michael Friedman, Paul Guyer, Robert Hanna, Tamar Schapiro, John Scott, Allen Wood, the anonymous referees for The Review of Politics, and the numerous participants at the November 2005 meeting of the North American Kant Society's Pacific Study Group at Stanford University.

${ }^{1}$ Allen Wood, Kant's Ethical Thought (Cambridge: Cambridge University Press, 1999), 321-23. 
emphasizes the way that politics serves moral purposes in Kant's thought and speaks of the "teleological bridge" that joins the ends of politics (republican government and perpetual peace) to the ends of ethics (kingdom of ends and the highest good), the latter of which motivate Kant's practical postulates of God and immortality, as we shall see. ${ }^{2}$ Howard Williams similarly contends that "Kant's conception of the final goal of politics is the apparently unrealizable dream of a genuinely ethical community in which the actions of individuals are guided by (the duties of) virtue" and that the advance toward it requires (according to Kant) Providence's "helping hand." ${ }^{3}$

As these quotations indicate, this latter group of scholars has helpfully gestured toward but not fully developed the idea that there is a close relationship between Kant's philosophy of right and his ethically grounded philosophy of religion. I will examine this largely unexplored relationship in this article, showing that Kant's political theory cannot be properly understood if it is separated from its ethico-theological context. Although Wood is right to emphasize the role that universal republicanism and perpetual peace play in advancing human happiness, they are necessary conditions for ethical community as well-whether its form is particular (e.g., earthly religious orders) or universal (e.g., a kingdom of ends in this life or the next one)because they encourage the development of our ethical capacities and thereby aid our obligatory pursuit of the highest good. Furthermore, the type of transparency specific to the political realm, publicity, and the mutual confidence it engenders are preparations for the fuller forms of transparency and trust realized in temporal ethical communities and especially in the afterlife.

To defend these claims, though, I must simultaneously explore Kant's ethico-theological arguments for God and immortality, as the essential role of transparency in these arguments has not been previously noticed. I will show that warranted belief in our motivational transparency (to both God and our fellow humans in the afterlife) is required to resolve a tension in Kant's practical philosophy-a tension that threatens to undermine his moral religion-between two conflicting definitions of human ends: as necessarily achievable goals (second Critique) and as unachievable standards or criteria (Rechtslehre). In the course of doing so, I shall examine the close bond between the objective ends of perpetual peace and the highest good, the former of which serves as a necessary condition for the latter. As we shall see, the relationship between political and ethico-religious ends explains why political community acts as a precondition for ethico-religious forms of community and why publicity lays the groundwork for the imperfect transparency of earthly ethical community and the perfect transparency of a

${ }^{2}$ Patrick Riley, Kant's Political Philosophy (Totowa: Rowman and Littlefield, 1983), 17.

${ }^{3}$ Howard Williams, Kant's Political Philosophy (Oxford: Basil Blackwell, 1983), 265, 268. 
noumenal kingdom of ends. I shall conclude the article by briefly discussing its implications for the contemporary Kantian political theories of Jürgen Habermas and John Rawls.

\section{The Highest Good, God, and Immortality: A Synopsis of Kant's Ethico-Theological Arguments}

The highest good for Kant is happiness (Glückseligkeit) proportioned to virtue (Tugend), perfectly realized for all finite rational beings (CPrR 5:110-11). ${ }^{4}$ Virtue refers here to our moral self-perfection, understood as the ability to discharge our duty purely out of respect for the moral law and, consequently, without the need for any material incentives. Virtue, which Kant calls the supreme good, is the condition of our worthiness to be happy, which explains why happiness in the highest good is proportioned to it. The highest (or complete) good consists of happiness in addition to virtue because happiness is the universal subjective end of finite rational beings. A virtuous but unhappy species simply could not serve as the highest end for sentient creatures such as ourselves (CPrR 5:25). All willing requires an end, and just as happiness is the end of empirically practical reason, so the highest good is

\footnotetext{
${ }^{4}$ References to Kant will consist of (i) abbreviations for the works from which they were drawn (unless they are obvious in context) and (ii) the relevant volume and page references to the standard critical edition of Kant (Gesammelte Schriften, ed. Royal Prussian Academy of Sciences [Berlin: Georg Reimer, 1900]). The only exception will be for references to the Critique of Pure Reason (ed. and trans. Paul Guyer and Allen Wood [Cambridge: Cambridge University Press, 1998]), where the supplemental references will be to pages in the first (1781 or " $\mathrm{A}$ ") and second (1787 or " $\mathrm{B}$ ") editions of the work. What follows is a complete list of the abbreviations I will use, in alphabetical order by abbreviation, including the English translation used for each text: $\mathbf{C F}=$ Contest of the Faculties (Kant, Political Writings, ed. Hans Reiss, trans. H. B. Nisbet [Cambridge: Cambridge University Press, 1970], 176-90); CJ = Critique of the Power of Judgment, ed. Paul Guyer, trans. Paul Guyer and Eric Matthews (Cambridge: Cambridge University Press, 2000); CPrR $=$ Critique of Practical Reason (Kant, Practical Philosophy, ed. and trans. Mary Gregor [Cambridge: Cambridge University Press, 1996], 133-272); ET = "The End of All Things" (Kant, Religion within the Boundaries of Mere Reason and Other Writings, ed. and trans. Allen Wood and George di Giovanni [Cambridge: Cambridge University Press, 1998], 193-205); GMM = Groundwork of the Metaphysics of Morals (Kant, Practical Philosophy, 37-108); IUH = "Idea for a Universal History with a Cosmopolitan Purpose" (Kant, Political Writings, 41-53); $\mathbf{M M}=$ Metaphysics of Morals (consisting of the Rechtslehre [Doctrine of Right] and the Tugendlehre [Doctrine of Virtue]) (Kant, Practical Philosophy, 353-604); PP = "Toward Perpetual Peace" (Kant, Practical Philosophy, 311-52); Rel = Religion within the Boundaries of Mere Reason (Kant, Religion, 31-192); and $\mathbf{T} \& \mathbf{P}=$ "On the Common Saying: That May Be Correct in Theory, but It Is of No Use in Practice" (Kant, Practical Philosophy, 273-310).
} 
the end of pure practical reason (T\&P 8:279-80; Rel 6:4-8). Finally, the highest good is not distinct from but rather contains all other objective ends, such as those involved in the imperfect duties of virtue, for example, the mostly private end of perfecting oneself and the public end of advancing others' happiness (MM 6:379-98). ${ }^{5}$

With this rough definition of the highest good in hand, we can now move to the problem for which God and immortality will provide the solution: the antinomy of pure practical reason (CPrR 5:113-14). ${ }^{6}$ Kant's statement of the antinomy in the Critique of Practical Reason has been roundly criticized and reconstructed in various ways. In what follows, I will make use of Lewis White Beck's own reconstruction of the antinomy. ${ }^{7}$ As reconstructed, the two horns of the antinomy are

1. The highest good is possible (implied by pure practical reason);

2. The highest good is impossible (implied by theoretical reason).

As noted above, the moral law obligates us to adopt the highest good as the architectonic end of pure practical reason, and as Kant repeatedly says throughout his critical writings, ought implies can (A806/B834; CPrR 5:125; Rel $6: 45,47,62) .{ }^{8}$ What Kant means by this is that to set anything as an end, we must at least believe it to be possible; thus, if we are obliged to

${ }^{5}$ Also see Allen Wood, Kant's Moral Religion (Ithaca: Cornell University Press, 1970), 95-96, and Yirmiahu Yovel, Kant and the Philosophy of History (Princeton: Princeton University Press, 1980), 88-90. Some authors have argued that the highest good is superfluous to or even inconsistent with Kant's moral theory; see, for example, Lewis White Beck, Commentary on Kant's Critique of Practical Reason (Chicago: University of Chicago Press, 1960), 242-45, and Thomas Auxter, "The Unimportance of Kant's Highest Good," Journal of the History of Philosophy 17 (1979): 121-34. Others have defended its role, including John Silber, "Kant's Conception of the Highest Good as Immanent and Transcendent," Philosophical Review 68 (1959): 469-92, and Stephen Engstrom, "The Concept of the Highest Good in Kant's Moral Theory," Philosophy and Phenomenological Research 52 (1992): 747-80.

${ }^{6}$ An antinomy is "a contradiction ... between two equally binding laws" (Oxford English Dictionary, $2^{\text {nd }}$ ed. [Oxford: Oxford University Press, 1989]); also see Katrin Flikschuh, Kant and Modern Political Philosophy (Cambridge: Cambridge University Press, 2000), 50-79.

${ }^{7}$ Beck, Commentary, 247-48. More specifically, I am using Beck's second reconstruction, which is itself a modified version of an earlier reconstruction by August Messer, Kants Ethik (Leipzig: Veit, 1904), 88. Yovel concurs in Beck's second reconstruction (Kant and the Philosophy of History, $87 \mathrm{n}$ ). Among the numerous other scholars who have criticized and reconstructed the antinomy is Wood, Kant's Moral Religion, 25-34, 116.

${ }^{8}$ Also see Yovel, Kant and the Philosophy of History, 82-83, who notes that ability (können) is a necessary condition of obligation (sollen). 
pursue the highest good, we are authorized by pure practical reason to assume its possibility (CPrR 5:113-14). ${ }^{9}$ I will return to this point shortly.

Theoretical reason, on the other hand, denies its possibility because there is no necessary connection between its two constituent elements (virtue and happiness proportioned to it). First, there is no analytic connection between them: virtue and happiness are not identical, contrary to the opinions of ancient Greek Epicureans and Stoics - one can be happy without being virtuous, virtuous without being happy (CPrR 5:111-13, 5:126-27). Second, there is no synthetic connection between them: virtue cannot be the efficient cause of happiness because causation is dependent upon not only the will but also "knowledge of the laws of nature and the physical ability to use them for one's purposes" (CPrR 5:113, 124-25). As was the case with the antinomy's first horn, the (im)possibility of a synthetic connection between virtue and happiness is a matter of belief: as Kant explains, "the impossibility referred to is merely subjective, that is, our reason finds it impossible for it to conceive, in the mere course of nature, a connection so exactly proportioned as well as so thoroughly purposive between events occurring in the world in accordance with such different laws [i.e., moral vs. natural laws], though, as with everything else in nature that is purposive, it nevertheless cannot provethat is, set forth sufficiently on objective grounds - the impossibility of it in accordance with universal laws of nature" (CPrR 5:145; cf. MM 6:354-55).

What follows if the contradiction contained in this antinomy is left unresolved? That is, what is the practical import of the antinomy of pure practical reason? The most serious threats posed by an unresolved antinomy are to moral motivation and the unity of reason. Kant sees it as a "hindrance to moral resolve" and fears it will lead to us "seeing [moral] effort as entirely futile in its effects and thereby flagging in it" (Rel 6:5; CJ 5:446, 452-53). ${ }^{10}$ How, in short, can we ever motivate ourselves to promote an end that we believe to be impossible? Equally troubling is the cognitive instability that results because "the moral way of thinking has no way to persevere in its collision with theoretical reason's demand for a proof (of the possibility of the object of morality), but rather vacillates between practical commands and theoretical doubts" (CJ 5:472). What is needed is some form of reconciliation between practical and theoretical reason on this matter, one that takes place on practical reason's own terms. Kant argues that practical reason should have priority over theoretical reason but not contradict it, which requires the latter to accept propositions that, while lacking positive theoretical

${ }^{9}$ Also, see Wood, Kant's Moral Religion, 21-23, and his Kant's Rational Theology (Ithaca: Cornell University Press, 1978), 21-22.

${ }^{10}$ Also, see Wood, Kant's Moral Religion, 155-60. Yovel notes that a belief in the impotence of moral effort "would produce an attitude of passivity and retreat, undermining the psychological possibility of intending to promote the highest good" (Kant and the Philosophy of History, 102). 
warrant, "belong inseparably to the practical interest" (CPrR 5:119-21, 144 n). What sort of propositions does he have in mind here?

Kant proposes two postulates of practical reason-God and immortality-to resolve the antinomy of pure practical reason. He maintains that these two postulates neither contradict our theoretical knowledge nor receive positive warrant from it but that they do "belong inseparably to the practical interest" we have in believing the highest good to be attainable. How exactly do they fulfill this role? Let us begin with immortality. The supreme good, virtue, demands perfect conformity with and motivation by the moral law (i.e., purity), which is impossible for a finite rational being at any moment of his existence. What is possible is "endless progress" toward it, which God sees in one intellectual intuition. Such progress (in German, Annäherung: approach, approximation, or convergence, here towards purity of the will) is possible, however, only on the supposition of the immortality of the soul, so that moral self-perfection can continue unabated (CPrR 5:122-24). If this progress is insufficient to achieve purityand it will be-God will eliminate the deficit through "sanctifying grace," as he can penetrate to the good disposition (Gesinnung) within us and impute to us the remainder "as if we already possessed it here in full" (Rel 6:44, 75, 191-92). ${ }^{11}$ The postulate of immortality (supported by the postulate of God) is, therefore, a need of pure practical reason, because the perfect virtue it makes possible is the dominant component of our highest end.

The highest or complete good (happiness proportioned to virtue) demands something that is beyond human powers, given our limited control of nature, but we are, nevertheless, obliged to pursue it. We are driven, consequently, to postulate the existence of some ground that will help us establish this connection. For human beings, this ground must take the form of a benevolent, omnipotent deity (God) who wills that morality and happiness coincide and who possesses the power necessary to make them coincide, be it in this life or the next (CPrR 5:124-32, 140).

\section{Perpetual Peace as an Unachievable End in Kant's Rechtslehre}

As noted above, Kant maintains that in order to set something as an end, we must at least believe it to be possible; therefore, if we have a duty to set something (e.g., the highest good) as an end, we are authorized by the source of that duty-our own pure practical reason-to believe that end possible so long as this belief is not ruled out by theoretical (speculative) reason (CPrR 5:113-14). ${ }^{12}$ The first premise of this argument, that we can only set possible ends, plays an essential role both here and in the first horn of the antinomy taken as a whole. If, contrary to this premise, we could set an end without believing it to be possible, then the antinomy would apparently dissolve:

\footnotetext{
${ }^{11}$ Also, see Wood, Kant's Moral Religion, 120.

${ }^{12}$ Also, see ibid., 21-23, and Wood, Kant's Rational Theology, 21.
} 
our duty to set the highest good as an end would not compel us to believe in its possibility; consequently, the first horn of the antinomy would be blunted. Allen Wood offers an interesting counterexample to Kant's premise:

Suppose, for instance, that I am playing a chess game with the chess champion of the world. I am a novice at chess, and it would not be excessive humility for me to admit that I have absolutely no chance of beating the champion, that it is quite impossible in fact for me to win (not logically impossible, of course, but still quite impossible enough). But even conceding this, I might continue to play as best I can and play to all appearances with the goal of winning... . But here I am, with perfect rationality, pursuing an end (winning the game) while firmly believing that it is quite impossible for me to attain this end, and this would seem to be ruled out by what Kant has said. ${ }^{13}$

Wood argues, however, that this counterexample fails: one can play as well as one can without actually having the goal of winning (one might, Wood suggests, be looking for a draw or hoping to last a certain number of moves). In this case, having the goal of winning would simply be delusional, a failure on the part of the actor to behave rationally or to understand the meaning of purposive action. ${ }^{14}$

Wood's response to this counterexample is persuasive, as the pursuit of impossible ends does seem quixotic, even irrational. Nevertheless, the fact remains that apparently rational people do set themselves (subjectively) impossible ends, like the chess player of Wood's example or the moderately talented amateur runner who sets himself the ultimate goal of running a fourminute mile. How are we to explain such behavior? One approach might be to reconsider the definition of "end" that has been implicit in the discussion so far: roughly, an achievable goal. Consider an alternative, slightly weaker, definition of an end, which sees it as characterized by four qualities:

1. Guidance: it offers a direction for effort;

2. Feasibility of Approach: movement toward it is possible;

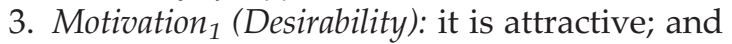

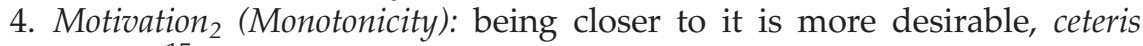
paribus. $^{15}$

${ }^{13}$ Wood, Kant's Moral Religion, 21.

${ }^{14}$ Ibid., $21-23$.

${ }^{15}$ This last condition is designed to rule out certain odd cases where an incomplete approach to a desirable object is worse than no approach at all. For example, an absence of guns may be ideal, but an initial, merely partial approach to this ideal may make things worse by disarming victims more often than criminals. What must be "held equal" to maintain the truth of the monotonicity claim here is something like the maintenance of the gun-ownership ratio between victims and criminals. See Robert S. Taylor, "A Game-Theoretic Model of Gun Control," International Review of Law and Economics 15 (1995): 269-88. 
This weaker notion of an end could also be described as a "standard" or "criterion." As stated, this definition is consistent with a variety of beliefs about the feasibility of the end itself: one might believe the end, so defined, to be certain, probable, possible, or even impossible. On this understanding, we could rationally set an end that we believe to be impossible. Consequently, if we were obligated to set some end, we would not be compelled to believe in its possibility-or, by implication, in the possibility of its preconditions (e.g., God and immortality in the case of the highest good).

This subtle distinction might rightly be considered an exercise in hairsplitting were it not for the fact that Kant, in his Rechtslehre, appears to define an end in precisely this way, thereby putting his moral arguments for God and immortality into jeopardy. Kant explicitly says in this work that perpetual peace, the "entire final end of the doctrine of right," is unachievable (MM 6:355). I will quote the relevant passages in full given their importance to my argument:

\begin{abstract}
So perpetual peace, the ultimate goal of the whole right of nations, is indeed an unachievable idea. Still, the political principles directed toward perpetual peace, of entering into alliances of states, which serve for continual approximation to it, are not unachievable. Instead, since continual approximation to it is a task based on duty and therefore on the right of human beings and of states, this can certainly be achieved.

What is incumbent upon us as a duty is rather to act in conformity with the idea of that end [perpetual peace], even if there is not the slightest theoretical likelihood that it can be realized, as long as its impossibility cannot be demonstrated either (MM 6:350, 354; emphasis added).
\end{abstract}

Notice that perpetual peace, though called "unachievable" in the first passage, does meet the four conditions of the weaker definition of an end that I laid out above: it provides direction for effort (Guidance); movement toward it is possible via approximation (Feasibility of Approach); and both it and the approach to it are desirable $\left(\right.$ Motivation $\left._{1 \& 2}\right)$. Notice as well that theoretical reason neither supports it nor conclusively rules it out. The same holds for the highest good, as I noted above: "[O]ur reason finds it impossible for it to conceive" of the highest good being achieved via mere natural means, but "it nevertheless cannot prove-that is, set forth sufficiently on objective grounds-the impossibility of it in accordance with universal laws of nature" (CPrR 5:145). In short, both the highest good and perpetual peace are subjectively but not objectively impossible. In the second Critique, this subjective impossibility generates an antinomy of reason that is only resolved via practical postulates that make the highest good subjectively possible. In the Rechtslehre, no such antinomy or postulates arise-a difference I think best explained by their different understandings of ends (as achievable goals and mere standards/criteria, respectively). 
Unsurprisingly, God plays almost no role in Kant's Rechtslehre: if the impossibility of perpetual peace is no longer a bar to adopting it as an end, then we have no need for God as a guarantor of its possibility. This conclusion, however, has subversive implications for Kant's moral religion. If we can set something as an end without believing it possible, then our need for the practical postulates of God and immortality will disappear. We can set the highest good as our end without thinking it feasible, devoting ourselves instead to an approximation to it (just as we do in the case of perpetual peace) and jettisoning any beliefs regarding supernatural assistance, which will be unneeded for the more limited moral task at hand and, therefore, unjustified on practical grounds. ${ }^{16}$

\section{The Relation of Perpetual Peace to the Highest Good}

How powerful is this particular critique of Kant's arguments for God and immortality? Is there some way for him to respond? He could just revert to his claim in the second Critique that we must believe in both the possibility of any end that we set and its preconditions, a claim that would apply just as readily to perpetual peace as to the highest good. The resulting modification to the Rechtslehre would bring its method closer to that of "Perpetual Peace," published only two years earlier, where Kant clearly does see God

\footnotetext{
${ }^{16}$ Kant's own religious beliefs, which are a contested matter, may be relevant in this context. Some scholars, such as John Hare, hold that he "personally continued to believe in the central doctrines he was brought up with," viz. those of Pietist Lutheranism (The Moral Gap: Kantian Ethics, Human Limits, and God's Assistance [New York: Oxford University Press, 1996], 38). Others, such as Ernst Cassirer (Kant's Life and Thought, trans. James Haden [New Haven: Yale University Press, 1981], 17-18, 377-97) and Manfred Kuehn, deny this and (in the case of Kuehn) even maintain that Kant was a lifelong religious skeptic. In his biography of Kant, Kuehn has Johann Georg Scheffner, Kant's oldest surviving friend, reflect on Kant's religious skepticism at his funeral: "Scheffner was only too much aware of Kant's belief that there was nothing to be expected after death. Though in his philosophy he had held out hope for eternal life and a future state, in his personal life he had been cold to such ideas. Scheffner had often heard Kant scoff at prayer and other religious practices. Organized religion filled him with ire. It was clear to anyone who knew Kant personally that he had no faith in a personal God. Having postulated God and immortality, he himself did not believe in either. His considered opinion was that such beliefs were just a matter of 'individual needs.' Kant himself felt no such need" (Kuehn, Kant: A Biography [Cambridge: Cambridge University Press, 2001], 2-3). We cannot rule out the possibility, then, that in the Rechtslehre Kant intended to subvert his earlier religious claims. However, I will proceed on the (defeasible) coherentist assumption that all of his works are meant to be consistent with one another and even mutually supporting. See Yovel (Kant and the Philosophy of History, 215-16) for an unsurprisingly brief discussion of Kant's infrequent practice of selfprotective esotericism.
} 
as a "guarantee of perpetual peace" (PP 8:360-62; cf. IUH 8:18, 30-31). ${ }^{17}$ If the former work is (as it appears to be) the exception in his writings on this matter, then making this modification would be a straightforward way to protect his moral arguments for God and immortality.

Suppose, on the other hand, that we take Kant's claims about unachievable ends in the Rechtslehre to be his final word on this subject, given the late date at which it was published. ${ }^{18}$ Is there some unnoticed difference between the highest good and perpetual peace (the highest political good) that would explain why the practical postulates of God and immortality are needed in the former case but not the latter? I will explore this possibility in the following section. In this section, I want to sharpen my critique of Kant by explicitly arguing for what was merely assumed above: the fundamental similarity of perpetual peace to the highest good, a relationship so close that the former is contained by and serves as a precondition of the latter.

The first, most important similarity between them is that both are objective ends derived from obligatory maxims (MM 6:382-86). Kant refers to perpetual peace as "the entire final end of the doctrine of right" (MM 6:355). The highest good is likewise presented as a necessary object of a will "determined a priori in its form," that is, by moral law-will as pure practical reason or as Wille rather than Willkür (CPrR 5:64; MM 6:213-14, 226). A second likeness is that nature acts as a hindrance to the achievement of both. Natural variation in languages and religions prevents the formation of a state of nations (Volkerstaat) that could bring about perpetual peace. Only a loose pacific federation (Volkerbund) offers any hope for a reduction of international conflict, but each state's retention of its war-making powers makes the resulting peace unstable (T\&P 8:310-13; PP 8:356-57, 367-68; MM 6:350). As we have seen, both our finite natural lifespan and our imperfect control over nature make realization of the highest good impossible without divine intervention, though the unaided approximation of it might still be possible.

\footnotetext{
${ }^{17}$ In "Perpetual Peace," Kant does insist upon a naturalized deity - he uses the terms "nature" and "providence" rather than God-but the difference seems semantic rather than substantive: he speaks of nature as a "great artist," calls its "purposiveness ... the profound wisdom of a higher cause," and says that we can make it "comprehensible to ourselves only if we ascribe it to the end of a creator of the world" (PP 8:360-62).

${ }^{18}$ Unfortunately, dating Kant's "final word" on unachievable ends raises some exegetical issues. The Rechtslehre and Tugendlehre (which together constitute the Metaphysics of Morals) were published separately in 1797, nearly two years after "Perpetual Peace." Scholars differ in their assessment of this work. Kuehn, for example, sees it as a "compilation of old lecture notes" and states that because of his advanced age, Kant "simply did not have the energy to satisfactorily pull together all the different strands of his arguments, let alone polish the work" (Kant, 396). If so, then "Perpetual Peace" might have a plausible claim to be the "final word." Wood, on the other hand, considers it "the definitive form of Kant's practical philosophy" (Kant's Ethical Thought, 13). My own evaluation of it is closest to Wood's.
} 
A third parallel is that the desirability of approach to both ends is continuous. I implied in the last section that both could be characterized as ends in the proposed weaker sense of the term ("end as standard"). This would be consistent, though, with a potential difference between them: the desirability of approach to one but not the other might be monotonic but discontinuous. This discontinuity would occur if there were a special value attached to actually achieving the end in question as opposed to coming very close to doing so. For example, suppose that you accept the three peaks challenge in Great Britain (of climbing Ben Nevis, Scafell, and Snowdon in under 24 hours). Coming close to doing so (e.g., completing it in 25 hours) would certainly have value, maybe even great value, but the jump in value from doing it in 24 hours instead would probably be significant. In the limit (assuming weak monotonicity), one could even imagine an end that has no value unless it is actually achieved; for example, a dike system may have no value until the last dike is finished, as any gap in the system prevents it from working at all (see figure 1). ${ }^{19}$ If the highest good but not perpetual peace were discontinuous in this sense, we might be able to explain why Kant postulates God and immortality for the former but not the latter. If anything short of complete attainment of an end were without value, then the need for divine intercession would be pressing, as full achievement here is much harder to imagine than a mere approach.

However, nowhere in Kant's writings does he clearly indicate that one conception but not the other is discontinuous in any sense. Indeed, it is initially hard to see why discontinuity would occur in either case:

1. Why would there be a discontinuous jump in desirability in moving from something exceedingly close to perpetual peace (e.g., perpetual peace minus a border skirmish between Bolivia and Paraguay) to perpetual peace itself?

2. Why would there be a discontinuous jump in desirability in moving from something exceedingly close to the highest good (e.g., the highest good minus a somewhat disproportionate virtue and happiness for one individual at one point in time) to the highest good itself?

A possible answer to this last question is that the concept of the highest good includes the idea of a necessary (if synthetic) connection between virtue and happiness, one modeled on natural laws, so that any exception, however minor, overturns the necessity and undermines its lawlikeness (CPrR 5:113). The persuasiveness of this claim, of course, would hinge on our evaluation of Kant's assumption that laws (natural or otherwise) must be exceptionless to be considered true laws-a claim that is in some tension with

${ }^{19}$ On the economic theory of dikes, see Jack Hirshleifer, "From Weakest-Link to Best-Shot: The Voluntary Provision of Public Goods," Public Choice 41 (1983): 371-86. 


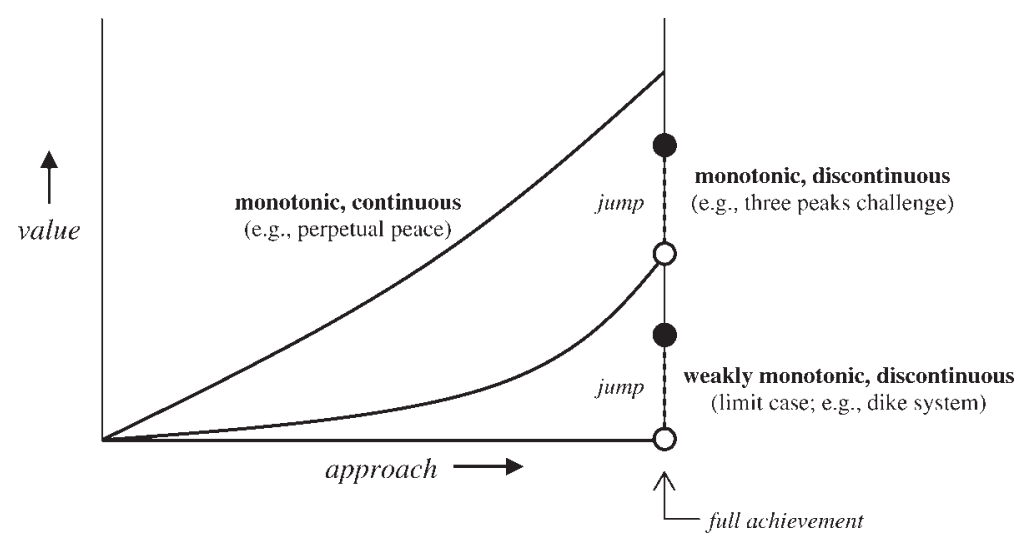

FIGURE 1.

the concept of law implicit in modern social science, for example. Even if we were persuaded by such a claim, however, it is difficult to see how this discontinuity could be large enough to explain Kant's postulation of God for the highest good but not perpetual peace. The mere approach to the highest good is extremely desirable, as it entails an ever-improving correspondence between virtue and happiness, which is approved by the "judgment of an impartial reason" even if it ultimately falls short of a lawlike necessity (CPrR 5:110). Thus, we are a long way from the limit case outlined above. If "an impartial rational spectator can take no delight in seeing the uninterrupted prosperity of a being graced with no feature of a pure and good will," then surely he can take delight in every coincidence of virtue and happiness, up to and including the last one needed to make the correspondence perfect (GMM 4:393).

I could continue to catalogue the family resemblances between perpetual peace and the highest good, but such a listing would understate the strength of the relationship in at least one important respect: a clear implication of Kant's claims about the two is that the highest good contains perpetual peace. This conclusion is a result of the following syllogism:

1. Major Premise: The highest good is "the whole object of pure practical reason," that is, it must contain all other objective ends (CPrR 5:109; cf. GMM 4:433);

2. Minor Premise: Perpetual peace is an objective end-indeed, "the entire final end of the doctrine of right," which is the first branch of that doctrine of morals yielded by our pure practical reason (MM 6:205, 355);

3. Conclusion: The highest good contains perpetual peace.

What exactly does it mean, though, for the highest good to contain perpetual peace? One way to interpret containment here is to think of perpetual peace as 
a condition for the attainment of the highest good and, therefore, of its two components, virtue and happiness.

Virtue. In his "Idea for a Universal History," Kant says that war stifles the development of man's latent moral capacities. In "Perpetual Peace," he makes the somewhat stronger claim that a rightful political order (domestic or international) actually encourages the development of these capacities: by providing assurance that respect for the rights of others will be reciprocated, a state or loose pacific federation creates an environment where our latent capacity to offer such respect "without regard for return" (i.e., out of reverence for the moral law) can flourish (IUH 8:25-26, 28; PP 8:375-76 n). Kant makes a similar claim in Religion, where political community is treated as a precondition for ethical community, an "association of human beings ... under the [public] laws of virtue" (Rel 6:94-95). I will further develop this point later in the paper.

Happiness. Perpetual peace promotes happiness principally by removing barriers to it. Kant's depiction of the cost to citizens of expansionary wars is vivid: the diversion of resources from education, crushing state debts, and the treatment of citizen-soldiers as "mere machines and tools" in the hands of the ruler, to be led like animals into war as if "on a hunt, and into battles as on a pleasure trip" (IUH 8:28; T\&P 8:311; PP 8:345; MM 6:345-46). The abolition of war will remove such hindrances to the growth of culture and the economy, and this growth will provide citizens with both the intellectual and material means to realize their idiosyncratic conceptions of happiness.

Perpetual peace is not, of course, a sufficient condition for the highest good. For example, there is little reason to believe that happiness will be better proportioned to virtue in a peaceful republican world - though at least the richly rewarded vice of despots will vanish. Still, if the highest good truly contains perpetual peace, then the full achievement of the former implies the full achievement of the latter; therefore, perpetual peace is a necessary condition for the highest good. Notice that this leaves open the possibility that God and/or immortality may be additional conditions for the achievement of the highest good, but in this section, at least, we have failed to discover a difference between the two conceptions that would explain why they would be conditions for one but not the other.

\section{Opacity, Perpetual Peace, and the Highest Good: Restating the Ethico-Theological Arguments}

Despite this intimate relationship between perpetual peace and the highest good, there is indeed a key difference between the two. This difference explains why the practical postulates of God and immortality are needed in the latter case but not the former: observability. Perpetual peace is an effectively observable condition of the highest good: we can generally see whether the world is approaching perpetual peace as a consequence of our political 
efforts to approximate a universal condition of right. For example, we can see whether wars are becoming less frequent over time, or at least whether they are becoming less frequent between states of a certain kind (e.g., republican states) and whether that kind is itself becoming more common (PP 8:350, MM 6:345-46, 354). Kant himself could perceive "a regular process of improvement in the political constitutions" of European societies over history, one that he thought might lead us toward a "republicanism of all states, together and separately" and to a consequent reduction in the frequency of war (IUH 8:29-30; MM 6:354). Even if we cannot know whether any peace we achieve is truly eternal, we can know whether the preconditions of perpetual peace-republican government, pacific federation, and cosmopolitan right-are being approached, and this makes it an effectively observable end of political action (PP 8:348-60). ${ }^{20}$

On the other hand, the highest good (and virtue in particular) is unobservable-at least to mortal eyes. Kant is adamant throughout his writings that we cannot observe virtue in others and remain uncertain about it in ourselves. Virtue, the "disposition to act from pure duty," is a matter of motivation rather than action. Owing to the tendency of self-deception, our own motives may be as obscure as those of others (Rel 6:51, ET 8:329-30). Kant's pessimism here is very difficult to exaggerate. In the famous opening passage of section 2 of the Groundwork, Kant admits that "no certain example can be cited of the disposition to act from pure duty," and he says in the Tugendlehre that

the depths of the human heart are unfathomable. Who knows himself well enough to say, when he feels the incentive to fulfill his duty, whether it proceeds entirely from the representation of the law or whether there are not many other sensible impulses contributing to it that look to one's advantage (or to avoiding what is detrimental) and that, in other circumstances, could just as well serve vice? (GMM 4:406-8; MM 6:447)

Consequently, the civilizing process-including the approach to perpetual peace itself-provides no proof that man is becoming more virtuous or that

${ }^{20}$ This paragraph and later ones may raise the question of how my paper's argument relates to Kant's philosophy of history. Scholars commonly divide over whether his historical philosophy is strictly about external progress (i.e., the pursuit of domestic and international right) or whether it is also strongly related to internal progress (i.e., the pursuit of a good moral disposition). Robert B. Louden (Kant's Impure Ethics: From Rational Beings to Human Beings [New York: Oxford University Press, 2000], 144-52) provides an excellent overview of this debate. As will become evident, I (like Louden himself) draw lessons from both sides: although history is necessarily based upon observable things, especially political actions, from which we draw motivational inferences at our own peril, Kant also believes that political and especially religious progress are the preconditions for ethical progress-by promoting and at times enforcing good behavior, states and churches help members develop the capacities and attitudes needed for morality. 
happiness is becoming better proportioned to virtue. Violations of rightboth domestic and international-are certainly evidence of continued human viciousness, but the obverse does not hold: their absence would not necessarily be a sign of virtue, because individuals and nations may act rightfully out of fear or prudence rather than out of respect for the moral law. As Kant remarks, a republican constitution is possible even for "a nation of devils," and greater civility is entirely consistent with greater hypocrisy and internal corruption (PP 8:366; IUH 8:26; Rel 6:27, 33-34, 93-94). ${ }^{21}$

Both here and elsewhere in Kant's writings, Jean-Jacques Rousseau's influence is prominent. ${ }^{22}$ In his Discourse on Inequality, Rousseau laments that civilized man, "in the midst of so much Philosophy, humanity, politeness, and Sublime maxims, [has] nothing more than a deceiving and frivolous exterior, honor without virtue." ${ }^{23}$ Kant similarly worries that "while the idea of morality is indeed present in culture, an application of this idea which only extends to the semblances of morality, as in love of honor and outward propriety, amounts merely to civilization [and is] nothing but illusion and outwardly glittering misery." He suspects that there are "many vices hidden under the appearance of virtue" in relations among fellow citizens and even intimate friends in civilized societies (IUH 8:26; Rel 6:33-34). As I noted above, the continuing movement toward perpetual peace and enlightenment should remove certain obstacles to happiness and virtue. It may even encourage the development of reason and discipline via "unsocial sociability" (IUH 8:20-21). However, what it can never rectify is our fundamental motivational opacity to ourselves and others, an opacity that prevents us from observing virtue and, therefore, the highest good.

If an end, like perpetual peace, is observable, then we can know whether we are successfully approaching it. However, if it is unobservable, like the highest good, then we cannot know; our efforts to approximate it may be failing or even leading us away from it, unbeknownst to us. Kant's pessimism about this pursuit is apparent even when he tries to reassure us about it. Regarding our quest for moral self-perfection, he warns that "one is never

${ }^{21}$ Also see Sharon Anderson-Gold, "God and Community: An Inquiry into the Religious Implications of the Highest Good," in Kant's Philosophy of Religion Reconsidered, ed. Philip J. Rossi and Michael Wreen (Bloomington: Indiana University Press, 1991), 124.

${ }^{22}$ See, e.g., Richard Velkley, Freedom and the End of Reason: On the Moral Foundation of Kant's Critical Philosophy (Chicago: University of Chicago Press, 1989); Richard Velkley, "The Crisis of the End of Reason in Kant's Philosophy and the Remarks of 1764-1765," in Kant and Political Philosophy: The Contemporary Legacy, ed. Ronald Beiner and William James Booth (New Haven: Yale University Press, 1993); and Ernst Cassirer, Rousseau, Kant, and Goethe, trans. James Gutman (New York: Harper and Row, 1963).

${ }^{23}$ Jean-Jacques Rousseau, The Discourses and Other Early Political Writings, ed. and trans. Victor Gourevitch (Cambridge: Cambridge University Press, 1997), 187. 
more easily deceived than in what promotes a good opinion of oneself." Inferences from better "life conduct" over time to an improved moral disposition, though psychologically necessary, are "conjecture" (Rel 6:68). Therefore, even if we can be obligated to set an unachievable end, as Kant suggests in his Rechtslehre, we cannot hope to approximate an end that we cannot observe. Such an end, like the highest good, would fail to meet even the weaker criteria for an end listed above: specifically, it would contravene the Guidance condition because an invisible target is, as a practical matter, no target at all. This conclusion strongly reinforces the concerns raised in an earlier section about the consequences of failing to resolve the antinomy of pure practical reason: namely, a sense of futility regarding moral effort and the disunity of reason. Practical reason commands us to pursue an invisible quarry, for whose existence theoretical reason provides not the least support. Such a farcical hunt will surely bring us to moral despair and set our reason at odds with itself. Rather than overturning Kant's antinomy, we have simply restated and sharpened it: the highest good both can (because it must) and cannot be approximated. Our duty to pursue it resembles an obligatory game of blind man's bluff.

We have not come full circle, however. Our newfound recognition of the importance of observability in Kant's moral religion (especially in regards to our motivational opacity) casts a different light on the practical postulates of God and immortality, which will serve to resolve the restated antinomy. Reversing the previous order, let us begin with God. Given our opacity, the need for the practical postulate of God is obvious: as Kant argues in the second Critique, the "author of the world ... must be omniscient in order to cognize my conduct even to my inmost disposition [Gesinnung] in all possible cases and throughout the future, omnipotent in order to bestow results appropriate to it," that is, happiness (CPrR 5:140; cf. Rel 6:48, 99). Without allowing the possibility of God, we could not conceive of how happiness (in this life or the next) could be proportioned to virtue, given its invisibility and our limited powers over the physical world. The antinomy would remain unresolved. In short, though we cannot see virtue ourselves, we are authorized by pure practical reason to believe in a deity who finds us motivationally transparent.

Let us now turn to immortality. Unlike the distribution of happiness to the virtuous, the achievement of virtue itself is a task to be carried out by man, not God, though God can create the conditions for moral self-perfection (MM $6: 386) .{ }^{24}$ Virtue requires the voluntary adoption of an objective end, which nobody (not even God) can do for us. At the same time, we find it difficult to imagine how we can approach complete virtue (i.e., purity) in this life,

\footnotetext{
${ }^{24}$ Wood correctly distinguishes between two things: achieving virtue for others, which is impossible, and creating the conditions for that achievement, which is undoubtedly possible and may even be obligatory, as in the case of the moral education of children (Kant's Moral Religion, 74-78).
} 
as it is a perfection "of which no rational being in the sensible world is capable at any moment of their existence" (CPrR 5:122). This inability is partly due to our capacity for self-deception: we can never be confident of the purity of our own motives (much less that of others), so our struggle for moral selfperfection must be accompanied by the pursuit of self-knowledge as well. Only by means of the latter effort can we identify the weaknesses in our character that must be reformed. Hence, Kant's suggestion that the postulate of immortality is a need of practical reason: only this assumption can assure us of the possibility of ceaseless progress toward perfect self-knowledge and moral purity for others and ourselves. ${ }^{25}$

How exactly does the postulate of immortality help us overcome the problem of self-deception and the related problem of the opacity of other people, both of which threaten to make our moral efforts futile? If the human heart is indeed "unfathomable," as Kant maintained, then we may only be able to achieve a very limited degree of self-knowledge, regardless of how long we pursue it. Moreover, why would the motives of other people become clearer to us in the afterlife? Granted, our ability to infer their motives might improve with time, but if their ability to hide their motives did the same, we would simply face a kind of "arms race" of detection and deception played out over eternity rather than over a human lifespan-an arms race that might be repeated in our effort to understand ourselves.

Without some assurance that we and our fellows can achieve and in fact are achieving real progress toward purity, we may despair and begin to doubt whether any improvement is occurring, leading us to slacken our obligatory efforts to perfect ourselves morally and to assist others in their own efforts. Given this pressing practical need, we may be justified in believing that in the afterlife virtue will become visible, not merely to God but to us as well. Kant points out that "we know nothing about the future, nor ought we to look for more than what stands in rational connection with the incentives of morality and their end" (Rel 6:161-62 n). Our need to believe in the reality of moral progress provides a "rational connection" between an afterlife of motivational transparency and the demands of the moral law. ${ }^{26}$ This view of immortality offers a new gloss on an old piece

${ }^{25}$ For more on the relationship between self-knowledge and virtue in Kant's ethics, see Jeanine Grenberg, Kant and the Ethics of Humility: A Story of Dependence, Corruption, and Virtue (Cambridge: Cambridge University Press, 2005), chap. 8.

${ }^{26}$ Kant also says that "if after this life another awaits him, he will persevere in it (in all appearances under different circumstances, yet according to the very same principle) and come ever closer to his goal of perfection" (Rel 6:68). If opacity is, as I have argued, a hindrance to moral progress, then these "different circumstances" would plausibly include motivational transparency. To be clear, Kant never claims this himself-I am extrapolating here-but if my overall argument is sound, this extension would appear necessary to preserve moral motivation and prevent despair. 
of Scripture as well: "For now we see through a glass, darkly; but then face to face: now I know in part; but then shall I know even as also I am known." ${ }^{27}$ The metaphor of religious enlightenment-of light being thrown in dark places and obscure visions made clear-nicely depicts the idea of the afterlife as a realm of transparency, not only between God and man but also among humans themselves. What we see only dimly now is the face of God and the goodness of men, yet we may reasonably hope for a clearer vision in a future life. Our faith in this coming lucidity is warranted by the support it offers to the moral life.

\section{Publicity, Transparency, and Ethical Community}

In an earlier section, I emphasized the similarities between perpetual peace (as the highest political good) and the highest good proper, but in the immediately preceding section, I appear to have opened up an unbridgeable chasm between the two. While I present the pursuit of perpetual peace as a worldly political project, I seem to portray the approach to the highest good as an otherworldly religious endeavor, one made possible only by the complete transparency achieved in the afterlife. In fact, the relationship between perpetual peace and the highest good remains a close one, though it is mediated by various kinds of ethical community. The type of transparency peculiar to political life-publicity-can be regarded as a preparation for the deeper varieties of transparency achieved in ethical community and the afterlife, which are themselves characterized by growing mutual confidence among participants and a correspondingly diminished need for mechanisms of coercion.

Many scholars have written on Kant's concept of publicity, especially as presented in the second appendix to "Perpetual Peace" (PP 8:381-86). Shell, for example, highlights three of its features inter alia: first, the "possibility of publicity is the juridical equivalent of the moral condition of universalizability, providing a test of [the] justice" of any proposed law; second, the publicity of political acts (made possible by a free press) makes it much more difficult for a state to adopt and enforce unjust policies; and third, publicity in both intellectual and political matters, by requiring all participants to submit to "the judgment of sound common reason," helps advance the acquisition of objective knowledge and the achievement of

${ }^{27} 1$ Corinthians 13:12 (King James Version). Kant would find it entirely appropriate that moral philosophy guide us in the interpretation of Scripture: he argues in Religion that "since the moral improvement of human beings constitutes the true end of all religion of reason, it will also contain the supreme principle of all scriptural exegesis" (Rel 6:112). For a critique of Kant's hermeneutics, see Yirmiahu Yovel, "Bible Interpretation as Philosophical Praxis: A Study of Spinoza and Kant," Journal of the History of Philosophy 11 (1973): 189-212. 
enlightenment. $^{28}$ There is an additional, much less noticed feature of Kantian publicity, however: its coordinating function. Kant begins his discussion of publicity in "Perpetual Peace" by maintaining that it is a necessary condition for justice and, therefore, right (PP 8:381). One reason for this is that Kant's universal principle of right calls for the reconciliation of all exercises of external freedom "in accordance with universal law." This reconciliation would be impossible, however, if such a law were kept secret, because the law itself (as a coordination device) as well as the rewards and penalties attached to it (as material incentives) can only function effectively if they are made public (MM 6:230-31).

This public coordination through right (Recht), by openly "checking the outbreak of unlawful inclinations," increases citizen confidence that others will behave justly. It lays the foundation for the development of a moral disposition: "[F]or each [citizen] now believes that he himself would indeed hold the concept of right sacred and follow it faithfully, if only he could expect every other to do likewise, and the government in part assures him of this; thereby a great step is taken toward morality (though it is not yet a moral step), toward being attached to this concept of duty even for its own sake, without regard for any return" (PP 8:375-76 n). A publicly rightful political order can, therefore, encourage the development of man's latent moral capacities, making him able to discharge virtuously his duties of right (MM 6:390-91). This being said, the transparency achieved via publicity is rather limited: citizens gain some assurance regarding the rightful behavior of others but remain profoundly uncertain of others' motivations. This uncertainty partly explains why right and coercion remain wedded (except in unusual cases, such as selfenforcing conventions, e.g., which side of the road to drive on). This point is especially true in the international realm, where the transparency that can be achieved through pacific federation and cosmopolitan law is even more limited.

However, domestic and international right creates a framework for other, deeper forms of community characterized by greater levels of transparency and trust. A key example is particular earthly religious community, at least when such community focuses - as genuine religion should, according to Kant-on moral improvement of congregants and final victory over evil (Rel 6:94-95). Kant describes such community as familial, where members strive for a "free, universal and enduring union of hearts" (Rel 6:102; cf.

\footnotetext{
${ }^{28}$ Susan Meld Shell, The Rights of Reason: A Study of Kant's Philosophy and Politics (Toronto: University of Toronto Press, 1980), 170-73. Insightful interpretations are also provided by Lisa Ellis, Kant's Politics: Provisional Theory for an Uncertain World (New Haven: Yale University Press, 2005), 104-11; John Christian Laursen, “The Subversive Kant: The Vocabulary of 'Public' and 'Publicity,'” in What Is Enlightenment?: Eighteenth-Century Answers and Twentieth-Century Questions, ed. James Schmidt (Berkeley: University of California Press, 1996), 263-66; and Allen Rosen, Kant's Theory of Justice (Ithaca: Cornell University Press, 1993), 181-86.
} 
MM 6:447). The rituals of these churches (e.g., public singing of hymns, communion) should serve this end by increasing confidence that all members are united in the pursuit of virtue (Rel 6:195-97, 6:199-200). Their confidence is severely limited, however, by the earthly opacity of virtue: they can never be certain of the virtue of their fellow congregants (or their own, for that matter) and must make uncertain inferences from outward shows of piety, charity, and so forth. Partly as a consequence of this uncertainty, coercion is still needed, though its forms are more subtle: apart from the continuing coercion of the supervisory framework of right, there exist the coercions of religious hierarchy (e.g., a priestly caste), required ritual performance (e.g., the hajj), social pressure and monitoring in congregations, among others (Rel 6:123 n ["compulsion"], $135 \mathrm{n}$ ["still indispensable"]).

Kant sees these more particular forms of ethical community being supplanted over time by a universal ethical community, what he calls "ethicocivil" (vs. "juridico-civil," i.e., political) society (Rel 6:94-95; cf. GMM 4:433 ["kingdom of ends"]). This cosmopolitan community for the promotion of virtue and the prevention of vice, a "church invisible," transcends the myriad forms of coercion applied by particular ecclesiastical religions. "[T]he degrading distinction between laity and clergy ceases, and equality springs from true freedom, yet without anarchy, for each indeed obeys the law (not the statutory one) which he has prescribed for himself" (Rel 6:101, 122). Although Kant plainly holds juridico-civil society (and its associated coercions) to be necessary for the creation of ethico-civil society (Rel 6:94), once the latter society emerges, the former may become superfluous. As Patrick Riley notes, "if everyone had a completely efficacious good will, there would be no Kantian politics to study: the kingdom of ends or corpus mysticum of rational beings would be the only kingdom, and an 'ethical commonwealth' ... could embrace the whole of humanity." ${ }^{29}$

Some scholars have argued that this secular ideal of a cosmopolitan ethicocivil society might serve as a practical substitute for Kant's otherworldly conception of the highest good. ${ }^{30}$ Unfortunately, the opacity of virtue is again an

\footnotetext{
${ }^{29}$ Riley, Kant's Political Philosophy, 17. I say "may," because even though a completely virtuous people would no longer have to be forced to conform to right, they might still need a public authority to establish and validate rights for purposes of voluntary coordination. Also note that such superfluity would hinge on virtue (and hence right) being fully attained, not simply approached.

${ }^{30}$ In his lectures on Kant, Rawls substitutes what he calls the "secular ideal" of a kingdom of ends for the highest good, which he considers a Leibnizian corruption of Kant's thought (Lectures on the History of Moral Philosophy, ed. Barbara Herman [Cambridge: Harvard University Press, 2000], 317). Similarly, Onora O'Neill asks the following question in a Tanner Lecture: "[M]ight we not construe the task of moral progress as a this-worldly, shared and historical, perhaps incompletable task, rather than as one that will provide each of us an occupation for an eternal afterlife?" ("Kant on Reason and Religion," in The Tanner Lectures on Human Values, ed. Grethe
} 
obstacle to the envisioned social transformation: pervasive uncertainty remains about whether moral progress-one's own or that of others-is occurring. We have seen that this uncertainty is itself a hindrance to moral progress, which is necessary for the eventual elimination of both ecclesiastical and political coercion. If increasing transparency is difficult to imagine even within the intimate confines of a church, how could it take place on a global scale? Kant himself suggests that earthly progress beyond that achieved through domestic and international right "would require a kind of new creation or supernatural influence" (CF 7:92; Rel 6:100). Might we not reasonably believe, then, that God will make virtue visible in this life rather than the next, so that a kingdom of ends on earth is approached by means of divine assistance?

Such a kingdom would be a step beyond perpetual peace, which involves merely rightful relations among people and nations, toward the realization of the highest good in this world. This earthly supplement to a Kantian afterlife would be a kind of chiliasm or millennialism (especially postmillennialism), which in its most generic form is faith in a future period of peace and plenty on earth achieved through progressive reforms by man and tutelary interventions by God. ${ }^{31}$ Such a millenarian variant might even serve as a substitute for the Kantian afterlife, but only if it could successfully deal with the problem of moral motivation. As I previously noted, the highest good incorporates all other objective ends, including my own moral self-perfection, which is my chief ethical responsibility. Can the ideal of an earthly kingdom of ends in the far future, long after I have ceased to exist, really hope to embrace this most personal part of the highest good? If not, then Kantian belief in the afterlife may still be practically necessary to supplement millenarian beliefs: a conscientious moral agent must believe that his own moral self-perfection as well as that of others can be approached, and a future worldly kingdom of ends may be an inadequate guarantee of that possibility.

Figure 2 summarizes the sequence of communities I have just sketched. Far from being unrelated to the highest good, perpetual peace provides the framework for its achievement. It underwrites the various forms of ethical community through domestic and international right and delivers a type of transparency-publicity - that encourages mutual confidence among moral agents and prepares them for the deeper types of transparency and trust to be achieved in ethical community, whether in this life or the next. This

B. Peterson [Salt Lake City: University of Utah Press, 1997], 286). Also see Alexander Kaufman, Welfare in the Kantian State (Oxford: Oxford University Press, 1999), 79, and Velkley, Freedom and the End of Reason, 153.

${ }^{31}$ For a discussion of the various forms of millennialism, see Frederic Baumgartner, Longing for the End: A History of Millennialism in Western Civilization (New York: St. Martin's Press, 1999). 


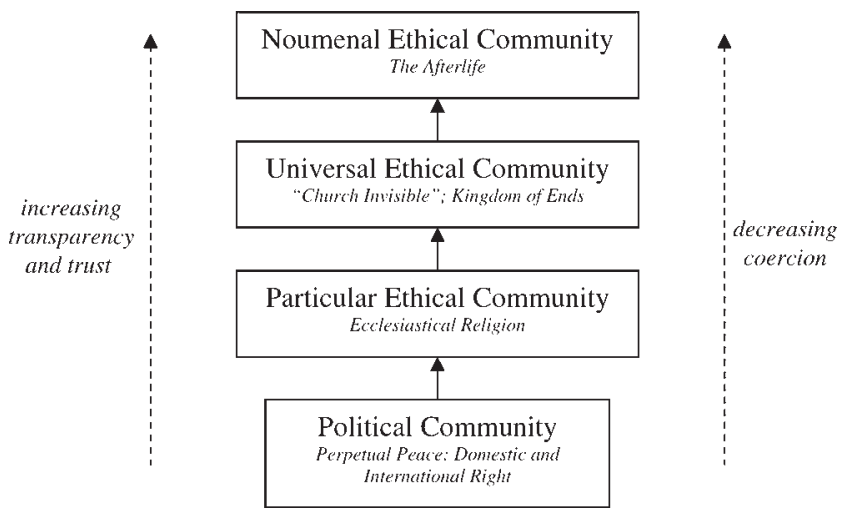

FIGURE 2.

deepening transparency and trust will reassure moral agents of the reality of progress toward perfect virtue, further encouraging the hard internal struggle toward this goal and creating the basis for the supernatural provision of a happiness fitting to it. Even if the approach to the highest good is ultimately an otherworldly task aided by a divinity, the groundwork for it is laid in this world via republican government, pacific federation, and cosmopolitan right-for Kant, the transcendent has its roots in the temporal.

\section{Conclusion}

Kant's political and religious doctrines are vital components of his practical philosophy, yet their relationship has remained largely unexplored until now. As we have seen, domestic and international right provides a framework for the development of ethical communities, including a kingdom of ends and even the noumenal ethical community of an afterlife. The transparency and trust achieved in these ethical communities are anticipated in rightful political society by publicity and the mutual confidence among citizens that it helps to engender. Political right and perpetual peace encourage the development of latent ethical capacities and clear away persistent obstacles to happiness. Thus, they prepare the way for our achievement (with divine assistance) of the highest good, whether in this life or the next.

One can detect the echo of Kant's ethico-religious ideal of transparency in the writings of Jürgen Habermas and other discursive democrats. Habermas sees deliberative politics as the only form of democratic practice that can claim legitimacy, and his "ideal speech situation" provides a model for such politics, one characterized by universal participation, contestability of claims, and motivational transparency. Unlike Rawls's "original position," which serves a merely heuristic function, Habermas's ideal communication community is the archetype for deliberative democratic 
institutions, including the public sphere. ${ }^{32}$ The kind of motivational transparency that he envisions, though-namely, that all participants are known to debate the validity of norms in good faith-is more of an ethico-religious ideal than a political ideal, as it presupposes a level of openness and trust more characteristic of the kingdom of ends or a noumenal ethical community than of any possible earthly political order. Despite Habermas's desire to avoid the metaphysical elements of Kant, his own political commitments may push him in that direction. ${ }^{33}$

John Rawls's political theory may appear less susceptible to metaphysical interpretations, at least following his "political turn" in the mid-1980s. However, justice as fairness-even in its political-liberal incarnationretains ethical elements, especially the idea that reasonable citizens desire a just social world "for its own sake," not only as a means to their own ends. ${ }^{34}$ Kant would judge this "virtuous justice": citizens in a Rawlsian wellordered society do the right things for the right reasons, and such a society can therefore be deemed "an interpretation of the idea of a kingdom of ends," as Rawls says in an earlier paper (MM 6:390-91). ${ }^{35}$ This well-ordered society, like the kingdom of ends, is governed by principles that serve as "publicly acknowledged and fully effective moral constitutions of social life"; moreover, there is a "general awareness of their universal acceptance," so that fellow citizens can trust each other's motives. ${ }^{36}$ As a result, Rawls's theory may ultimately be as dependent upon an ethico-religious ideal of transparency as Habermas's. I have contended in this essay that Kant's practical philosophy is an organic whole, with thoroughly integrated political, ethical, and religious elements. I, therefore, believe that these efforts by contemporary

\footnotetext{
${ }^{32}$ Jürgen Habermas, "Discourse Ethics: Notes on Philosophical Justification," in Moral Consciousness and Communicative Action, trans. Christian Lenhart and Shierry Weber Nicholson (Cambridge: The MIT Press, 1980), 86. Habermas warns against the temptation to "improperly hypostatize the system of validity claims on which speech is based"; he avers that ideal communication communities are not political models but rather "thought experiments" (Jürgen Habermas, Between Facts and Norms: Contributions to a Discourse Theory of Law and Democracy, trans. William Rehg [Cambridge: The MIT Press, 1996], 322-23). Nevertheless, his own language frequently belies this claim, as when he states that "the theory of communicative action detranscendentalizes the noumenal realm only to have the idealizing force of context-transcending anticipations settle in the unavoidable pragmatic presuppositions of speech, and hence in the heart of ordinary, everyday communicative practice" (19). This statement is properly understood not as a rejection of guiding ideals but rather as an affirmation of their immanent (rather than transcendent) quality.

${ }^{33}$ Ibid., 10.

${ }^{34}$ John Rawls, Political Liberalism (New York: Columbia University Press, 1993), 50.

${ }^{35}$ John Rawls, Collected Papers, ed. Samuel Freeman (Cambridge, MA: Harvard University Press, 1999), 264.

${ }^{36}$ John Rawls, A Theory of Justice, rev. ed. (Cambridge, MA: Harvard University Press, 1999), 115, cf. 221.
} 
Kantians to pick it selectively in the service of their secular political theories are unlikely to be fruitful, though a full defense of this claim will have to wait for another occasion. ${ }^{37}$

Habermas and Rawls, like Kant, endorse the political practice of publicity and consider it a key determinant of overall levels of public confidence in rulers and fellow citizens. ${ }^{38}$ While this confidence may appear to serve only temporal political ends, it prepares the ground for richer forms of confidence to grow, ones rooted in transpolitical communities and their objectives. Just as rightful governance imperfectly realizes many ends of morality in this life, so publicity reflects particular aspects of transparency promised in the afterlife. Publicity is more than a simulacrum of such transparency, however: it is an essential component of it, a foundation stone for an otherworldly edifice constructed within the bounds of mere reason.

${ }^{37}$ I do not intend to imply by these comments that Habermas and Rawls are antireligious or even that their theories lack a kind of religious ethos-far from it. For the former's views on religion and its relationship to philosophy (and critical theory more specifically), see Jürgen Habermas, Religion and Rationality: Essays on Reason, God and Modernity, ed. Eduardo Mendieta (Cambridge: The MIT Press, 2002). Rawls became more deeply religious during his last two years as a Princeton undergraduate, but infantry service in the Pacific during World War II permanently changed this, after which he was "no longer orthodox," as he put it, though he appears to have retained some belief in a nonvoluntarist, non-Christian moral theism ("On My Religion," in John Rawls, A Brief Inquiry into the Meaning of Sin and Faith, ed. Joshua Cohen and Thomas Nagel [Cambridge, MA: Harvard University Press, 2009], 259-70).

${ }^{38}$ Rawls, A Theory of Justice, 115; Jürgen Habermas, The Structural Transformation of the Public Sphere: An Inquiry into a Category of Bourgeois Society, trans. Thomas Burger (Cambridge: The MIT Press, 1989), 208-9, and Habermas, Between Facts and Norms, 171, 183. 